\title{
Brevundimonas aveniformis sp. nov., a stalked species isolated from activated sludge
}

Correspondence
Che Ok Jeon
cojeon@gnu.ac.kr

\author{
Seung Hyun Ryu, ${ }^{1}$ Minjeong Park, ${ }^{1}$ Jung Ro Lee, ${ }^{1}$ Pil-Yong Yun ${ }^{2}$ \\ and Che OK Jeon ${ }^{1}$ \\ ${ }^{1}$ Division of Applied Life Science, EB-NCRC, PMBBRC, Gyeongsang National University, \\ Jinju 660-701, Republic of Korea \\ ${ }^{2}$ Jeju Hi-Tech industry Development Institute, 4-8 Ara-1 dong, Jeju 690-121, \\ Republic of Korea
}

Activated sludge processes involving cyclical changes between anaerobic and aerobic conditions have been employed to remove phosphate from wastewater, and are increasingly used to reduce eutrophication in lakes (Mino et al., 1987; Jeon \& Park, 2000). Insight into the bacterial community responsible for phosphorus removal is a prerequisite for an understanding of the enhanced biological phosphorus removal (EBPR) mechanism and for controlling the EBPR processes. Pseudomonas diminuta and Pseudomonas vesicularis, first described by Leifson \& Hugh (1954), were reclassified into a novel genus, Brevundimonas (in the Alphaproteobacteria) with Brevundimonas diminuta by Segers et al. (1994). Later, several Caulobacter species and subspecies were transferred to the genus Brevundimonas, and novel Brevundimonas species isolated from diverse habitats, especially marine habitats, were described (Abraham et al., 1999; Fritz et al., 2005; Li et al.,

Abbreviation: EBPR, enhanced biological phosphorus removal.

The GenBank/EMBL/DDBJ accession number for the 16S rRNA gene sequence of strain $\mathrm{EMB102}{ }^{\top}$ is $\mathrm{DO} 372984$.

The cellular fatty acid compositions and substrate-assimilation data for strain EMB102 ${ }^{\top}$ and some related Brevundimonas species are available in supplementary tables available with the online version of this paper.
2004). In this study, we describe the taxonomic characterization of a novel species, isolated from activated sludge that was able to perform EBPR, and we propose a novel species of the genus Brevundimonas.

Strain EMB102 ${ }^{\mathrm{T}}$ was isolated from activated sludge performing EBPR in a laboratory-scale sequencing batch reactor. Sodium acetate was supplied as a sole carbon source and the operation of the sequencing batch reactor was as described elsewhere (Jeon et al., 2003). The sludge sample was serially diluted with $1 \%(\mathrm{w} / \mathrm{v})$ saline solution and spread on R2A agar (Difco) and incubated at $20^{\circ} \mathrm{C}$ for 7 days. Subcultivation was conducted on R2A agar at $30^{\circ} \mathrm{C}$ for 3 days.

Physiological characteristics of strain $\mathrm{EMB} 102^{\mathrm{T}}$ and type strains of members of the genus Brevundimonas were examined; the isolate was grown on R2A medium at different temperatures and $\mathrm{pH}$ values. $\mathrm{R} 2 \mathrm{~A}$ media with different $\mathrm{pHs}$ were prepared as described previously (Gomori, 1955). Gram staining was performed using a bioMérieux Gram stain kit according to the instructions of the manufacturer. Oxidase activity was tested by assessing the oxidation of $1 \%(\mathrm{w} / \mathrm{v})$ tetramethyl-p-phenylenediamine (Merck), and catalase activity was evaluated by observing 
the production of oxygen bubbles in a $3 \%(\mathrm{v} / \mathrm{v})$ aqueous hydrogen peroxide solution. Cell morphology and motility were studied using phase-contrast microscopy and transmission electron microscopy (JEM-1010; JEOL) at different growth stages, as described by Jeon et al. (2005). Hydrolysis of casein, gelatin, Tweens 80 and 20, aesculin, urea, tyrosine and starch was investigated on R2A agar after 7 days incubation, as described previously (Lanyi, 1987; Gerhardt et al., 1994). Growth at various $\mathrm{NaCl}$ concentrations was investigated in 10-fold-diluted trypticase soy broth (Difco). Nitrate reduction was determined according to the method of Lanyi (1987), and acid production from carbohydrates was tested as described by Leifson (1963). Oxidation of various substrates was determined by using the Biolog GN2 MicroPlate assay as recommended by the manufacturer, and additional enzyme activities and biochemical features were determined by using API kits (API ZYM and API 20E) at $30{ }^{\circ} \mathrm{C}$ as recommended by the manufacturer (bioMérieux). Growth of strain $\mathrm{EMB} 102^{\mathrm{T}}$ was obtained at temperatures between 15 and $35^{\circ} \mathrm{C}$, the optimum growth temperature being $30^{\circ} \mathrm{C}$. The strain grew at $\mathrm{pH} 6.0-9.0$, the optimum being at $\mathrm{pH}$ 7.5-8.5. Cells of strain $\mathrm{EMB} 102^{\mathrm{T}}$ were found to be Gram-negative and oxidase- and catalase-positive. During the early growth stage, the cells were motile by means of single polar flagella, but they gradually lost their flagella and each produced a stalk at the flagellated pole: this is the typical lifestyle of some species of the genera Caulobacter and Brevundimonas (Fig. 1). The number of stalked cells lacking motility increased with increasing cultivation time. The cylindrical body of the cell was approximately $0.3-0.4 \mu \mathrm{m}$ in diameter and $1.0-2.0 \mu \mathrm{m}$ in length. Anaerobic growth was not observed at 7 days cultivation on $\mathrm{R} 2 \mathrm{~A}$ agar at $30^{\circ} \mathrm{C}$, but weak growth was observed after 16 days. The strain reduced nitrate to nitrite and produced nitrogen gas. Other phenotypic features of strain EMB102 $2^{\mathrm{T}}$ and type strains of Brevundimonas species are presented in Table 1 and in the description of the novel species. The oxidation results for various substrates tested with the Biolog GN2 MicroPlate system are shown in

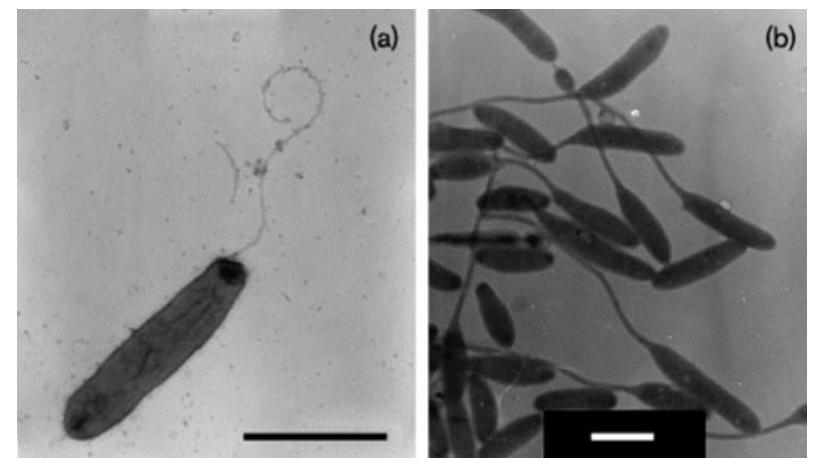

Fig. 1. Transmission electron micrographs showing the general morphology of negatively stained cells of strain $\mathrm{EMB} 102^{\top}$ after growth at $30^{\circ} \mathrm{C}$ in R2A broth. (a) Motile cell with a flagellum; (b) non-motile stalked cells without flagella. Bars, $1 \mu \mathrm{m}$.
Supplementary Table S1 ( available with the online version of this paper). Some of these results are in accordance with the characteristics of members of the genus Brevundimonas, whereas some others allow the differentiation of strain EMB $102^{\mathrm{T}}$ from closely related species of this genus (Table 1).

For analysis of fatty acid methyl esters, cells of strain $\mathrm{EMB} 102^{\mathrm{T}}$ and type strains of Brevundimonas species were harvested from agar plates after incubation for 3 days on LMG medium no. 221 at the relevant optimal temperature. Analysis of the fatty acid methyl esters was performed according to the instructions of the Microbial Identification System (MIDI; Microbial ID). Analyses of isoprenoid quinones and polar lipids were carried out using the methods described by Komagata \& Suzuki (1987) and Batrakov et al. (1997), respectively. The DNA G+C content of strain EMB $102^{\mathrm{T}}$ was determined using HPLC apparatus fitted with a reversed-phase column (GROM-SIL 100 ODS-2FE, GROM) according to the method of Tamaoka \& Komagata (1984). The major cellular fatty acids present were $\mathrm{C}_{18: 1} \omega 7 c$, $\mathrm{C}_{16: 0}$ and $\mathrm{C}_{15: 0}$. The main hydroxy fatty acid was iso- $\mathrm{C}_{17: 0}$ $3-\mathrm{OH}$ on LMG medium no. 221, and the fatty acid profile was generally similar to those of other Brevundimonas species; however, the proportions of some fatty acids, such as $\mathrm{C}_{18: 1} 11$-methyl $\omega 7 c, \mathrm{C}_{17: 1} \omega 7 c$ and $\mathrm{C}_{19: 0}$ cyclo $\omega 8 c$ were different (see Supplementary Table S2 available with the online version of this paper). The predominant polar lipid of strain $\mathrm{EMB}_{102}{ }^{\mathrm{T}}$ was phosphatidylglycerol, the major respiratory lipoquinone was Q-10 and the DNA G+C content was $64.1 \mathrm{~mol} \%$. The major fatty acids, the major lipoquinone, the polar lipid profile and the $\mathrm{G}+\mathrm{C}$ content of strain $\mathrm{EMB} 102^{\mathrm{T}}$ are in accordance with those of members of the genus Brevundimonas (Abraham et al., 1999; Li et al., 2004; Fritz et al., 2005; Yoon et al., 2006).

The sequencing and assembly of the 16S rRNA gene were carried out as described by Lane (1991). The resultant $16 \mathrm{~S}$ rRNA gene sequence $(1403 \mathrm{nt})$ of strain $\mathrm{EMB} 102^{\mathrm{T}}$ was compared with those available from GenBank by using the BLAST program (www.ncbi.nlm.nih.gov/blast/) to determine an approximate phylogenetic affiliation; the gene sequences were aligned with those of closely related species by using the CLUSTAL W software program (Thompson et al., 1994). Phylogenetic trees were constructed using three different methods, i.e. the neighbour-joining, maximum-likelihood and maximum-parsimony algorithms; these methods are available in PHYLIP software, version 3.6 (Felsenstein, 2002). Values for sequence similarity between the isolate and related members of the genus Brevundimonas were computed using SIMILARITY MATRIX, version 1.1 (Ribosomal Database Project II; http://35.8.164.52/html/; Cole et al., 2003). A bootstrap analysis was performed according to the algorithm of the Kimura two-parameter model (Kimura, 1980) of the neighbour-joining method in the PHYLIP package. DNA-DNA hybridization experiments were carried out to evaluate the genomic DNA relatedness between strain $\mathrm{EMB} 102^{\mathrm{T}}$ and Brevundimonas nasdae 
Table 1. Phenotypic characteristics of strain $\mathrm{EMB} 102^{\top}$ and some related Brevundimonas species

Taxa: 1, strain EMB102 ${ }^{\mathrm{T}}$; 2, Brevundimonas diminuta; 3, Brevundimonas kwangchunensis; 4, Brevundimonas alba; 5, Brevundimonas aurantiaca; 6, Brevundimonas intermedia; 7, Brevundimonas nasdae; 8, Brevundimonas vesicularis. Symbols: +, positive; -, negative; w, weakly positive reaction. Data in parentheses are for type strains. Type strains of all species were positive for oxidase and catalase (this study).

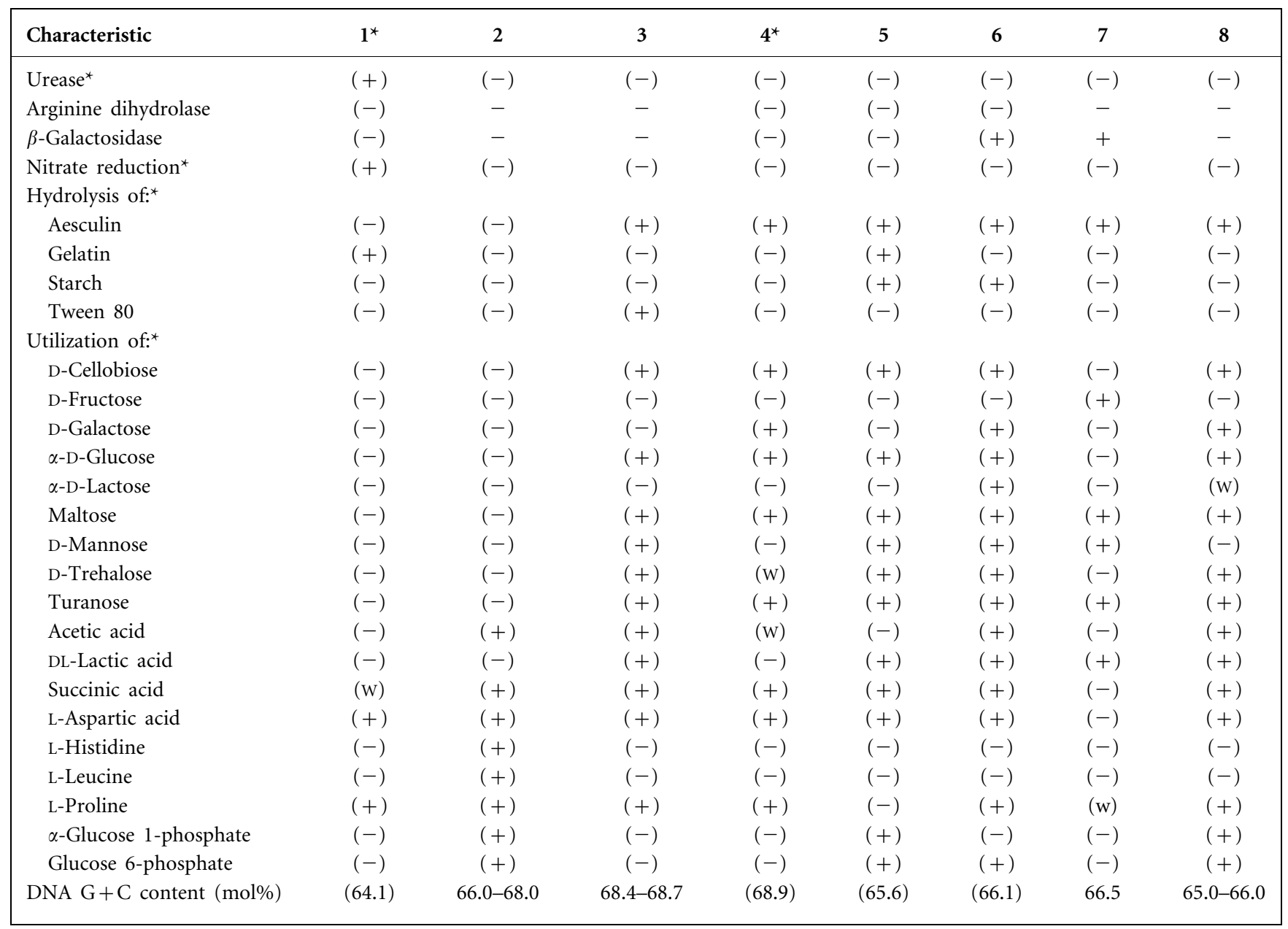

${ }^{\star}$ Data from this study. Other data were taken from Yoon et al. (2006).

W1-2B ${ }^{\mathrm{T}}$, Brevundimonas vesicularis LMG $2350^{\mathrm{T}}$, Brevundimonas intermedia ATCC $15262^{\mathrm{T}}$, Brevundimonas kwangchunensis KSL- $102^{\mathrm{T}}$ and Brevundimonas aurantiaca DSM $4731^{\mathrm{T}}$, which exhibited $16 \mathrm{~S}$ rRNA gene sequence similarities above $97 \%$. The extracted genomic DNAs were fragmented with HaeIII for slot hybridization. The digested DNAs were serially diluted and loaded into slots (three replications for each sample) and their DNAs used individually as labelled DNA probes for cross-hybridization. Random-primed DNA labelling with digoxigenin-dUTP and hybridization (hybridization at $51.5^{\circ} \mathrm{C}$; washing at $68^{\circ} \mathrm{C}$ ) were performed using the DIG High Prime DNA labelling kit (Roche Applied Science) according to the instructions of the manufacturer and using standard procedures (Sambrook \& Russell, 2001; Lim et al., 2005). The signals of the series of dilutions were quantified using Bio-Rad GelDoc scanning software. The signals produced by self-hybridization were inferred as
$100 \%$ and the homology percentages were calculated from samples analysed in triplicate.

The neighbour-joining phylogenetic tree constructed on the basis of $16 \mathrm{~S}$ rRNA gene sequences indicated that strain $\mathrm{EMB} 102^{\mathrm{T}}$ formed a distinct phyletic lineage within the genus Brevundimonas (Fig. 2). The topologies of the phylogenetic trees constructed using the maximum-likelihood and maximum-parsimony algorithms also supported the notion that the isolate belongs to the genus Brevundimonas and can be differentiated from the other species of the genus (data not shown). Comparative 16S rRNA gene sequence analyses showed that the isolate was most closely related to B. nasdae $\mathrm{W} 1-2 \mathrm{~B}^{\mathrm{T}}, B$. vesicularis $\mathrm{LMG} 2350^{\mathrm{T}}$, B. intermedia ATCC $15262^{\mathrm{T}}$, B. kwangchunensis KSL- $102^{\mathrm{T}}$ and B. aurantiaca DSM $4731^{\mathrm{T}}$, with similarities of 97.5, 97.5, 97.3, 97.2 and $97.2 \%$, respectively. However, the values for 


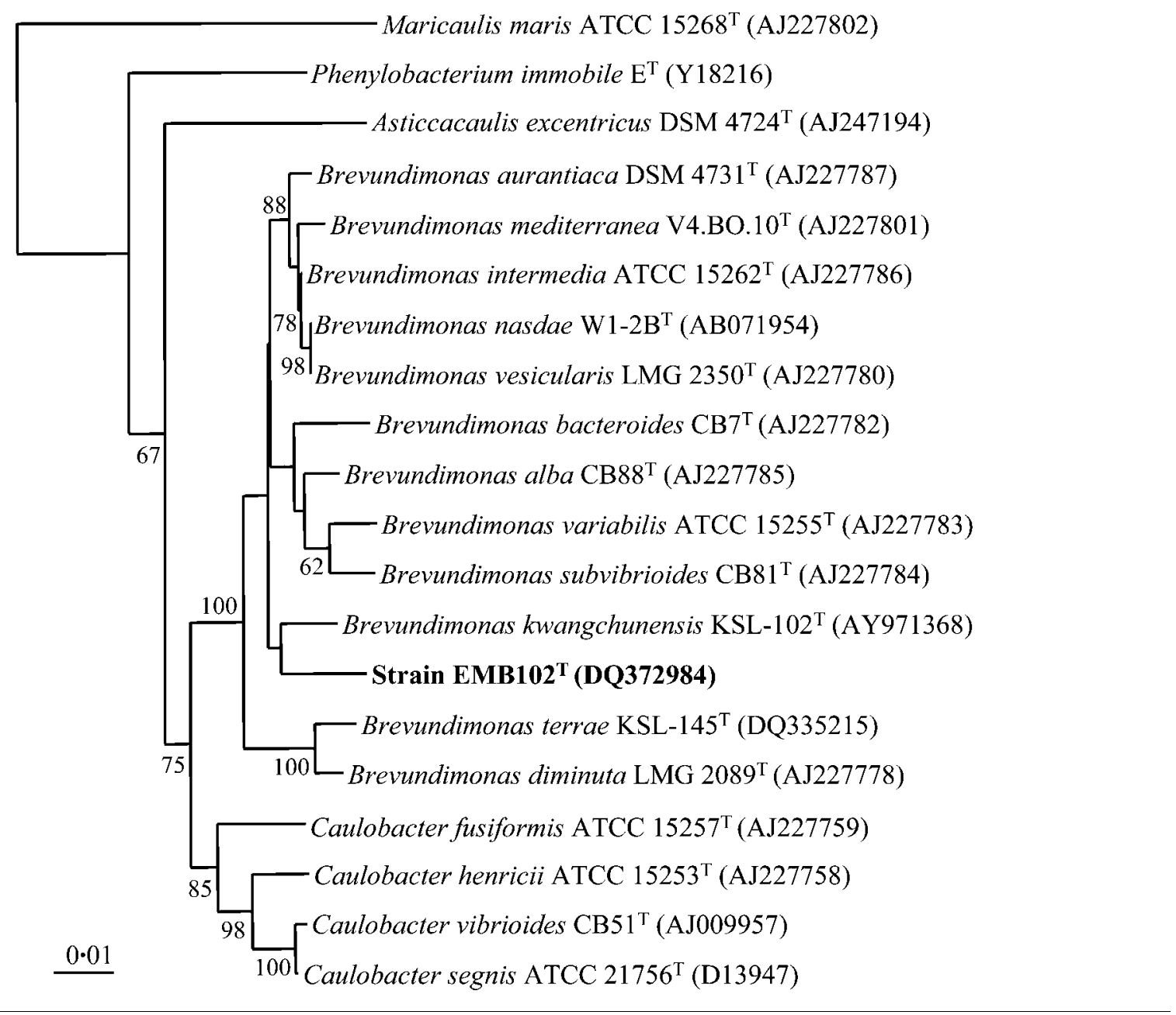

Fig. 2. Neighbour-joining phylogenetic tree, based on $16 \mathrm{~S}$ rRNA gene sequences, showing the relationships of strain EMB $102^{\top}$ and related taxa. Bootstrap percentages (from 1000 replicates) are shown if greater than $50 \%$. Maricaulis maris ATCC $15268^{\top}$ was used as an outgroup. Bar, 0.01 changes per nucleotide position.

DNA-DNA relatedness between strain $\mathrm{EMB} 102^{\mathrm{T}}$ and the related Brevundimonas species were below $15.0 \%$. Therefore, the physiological, biochemical and phylogenetic properties of strain $\mathrm{EMB} 102^{\mathrm{T}}$ support its description as a novel species within the genus Brevundimonas, for which the name Brevundimonas aveniformis sp. nov. is proposed.

\section{Description of Brevundimonas aveniformis sp. nov.}

Brevundimonas aveniformis (a.ven.i.for'mis. L. n. avena stalk; L. suff. -formis of the shape of; N.L. fem. adj. aveniformis stalk-shaped).

Cells are Gram-negative, rod-like bacteria that can produce stalks; the size of the main cell body is $0.3-0.4 \times 1.0-2.0 \mu \mathrm{m}$. Colonies on R2A agar are white, slightly raised and circular with entire margins. Growth occurs optimally at $30^{\circ} \mathrm{C}$ and $\mathrm{pH}$ 7.5-8.5. The optimum $\mathrm{NaCl}$ concentration is $0-1 \%(\mathrm{w} / \mathrm{v})$; no growth occurs at $\geqslant 3 \%$. Catalase- and oxidase-positive. Nitrate is reduced to nitrite and nitrogen gas is produced. Hydrolyses casein, urea, tyrosine and gelatin, but not Tween 80 and 20, aesculin or starch. Negative for indole, $\mathrm{H}_{2} \mathrm{~S}$ and acetoin production and citrate utilization (API 20E). Produces acids from raffinose, myoinositol, D-mannose and D-mannitol, but not from Dglucose, D-fructose, D-galactose, L-arabinose, melibiose, lactose, arbutin or salicin. Produces leucine arylamidase, valine arylamidase, naphthol-AS-BI-phosphohydrolase and urease, but not esterase (C4), lipase (C14), arginine dihydrolase, lysine decarboxylase, ornithine decarboxylase, cystine arylamidase, $\alpha$-galactosidase, $\beta$-galactosidase, $\beta$ glucuronidase, $\alpha$-glucosidase, $\beta$-glucosidase, $N$-acetyl- $\beta$ glucosaminidase, $\alpha$-mannosidase or $\alpha$-fucosidase. Weak enzymic activities are observed for esterase lipase (C8), alkaline phosphatase, trypsin, tryptophan deaminase, $\alpha$-chymotrypsin and acid phosphatase. The predominant polar lipid is phosphatidylglycerol. Utilizes glycogen, pyruvic acid methyl ester, $\beta$-hydroxybutyric acid, L-alaninamide, L-alanine, L-alanyl glycine, L-asparagine, L-aspartic 
acid, L-glutamic acid, glycyl L-aspartic acid, glycyl Lglutamic acid, L-histidine, L-proline, L-serine, L-threonine and urocanic acid (Biolog GN2). Other organic substrates included in Biolog GN2 MicroPlate system are not utilized. The major isoprenoid quinone is Q-10. The major cellular fatty acids are $\mathrm{C}_{18: 1} \omega 7 c, \mathrm{C}_{16: 0}$ and $\mathrm{C}_{15: 0}$, and the main hydroxy fatty acid is iso- $\mathrm{C}_{17: 0} 3-\mathrm{OH}$. The DNA G+C content is $64.1 \mathrm{~mol} \%$ (HPLC).

The type strain, EMB102 ${ }^{\mathrm{T}} \quad\left(=\mathrm{KCTC} \quad 12609^{\mathrm{T}}=\mathrm{DSM}\right.$ $17977^{\mathrm{T}}$ ), was isolated from activated sludge that performed EBPR in a laboratory-scale sequencing batch reactor.

\section{Acknowledgements}

These efforts were supported by grants from MOST/KOSEF to the Environmental Biotechnology National Core Research Center (grant R15-2003-012-02002-0) and to the 21C Frontier Microbial Genomics and Application Center Program (grant MG05-0104-4-0), Ministry of Science and Technology, Republic of Korea. S. H. R. and M. P. were supported by scholarships from the BK21 Program of the Ministry of Education and Human Resources Development in Korea.

\section{References}

Abraham, W.-R., Strömpl, C., Meyer, H., Lindholst, S., Moore, E. R. B., Christ, R., Vancanneyt, M., Tindall, B. J., Bennasar, A. \& other authors (1999). Phylogeny and polyphasic taxonomy of Caulobacter species. Proposal of Maricaulis gen. nov. with Maricaulis maris (Poindexter) comb. nov. as the type species, and emended description of the genera Brevundimonas and Caulobacter. Int J Syst Bacteriol 49, 1053-1073.

Batrakov, S. G., Nikitin, D. I., Sheichenko, V. I. \& Ruzhitsky, A. O. (1997). Unusual lipid composition of the gram-negative, freshwater, stalked bacterium Caulobacter bacteroides NP-105. Biochim Biophys Acta 1347, 127-139.

Cole, J. R., Chai, B., Marsh, T. L., Farris, R. J., Wang, Q., Kulam, S. A., Chandra, S., McGarrell, D. M., Schmidt, T. M. \& other authors (2003). The ribosomal database project (RDP-II): previewing a new autoaligner that allows regular updates and the new prokaryotic taxonomy. Nucleic Acids Res 31, 442-443.

Felsenstein, J. (2002). PHYLIP (phylogeny inference package), version 3.6a. Department of Genome Sciences, University of Washington, Seattle, USA.

Fritz, I., Strömpl, C., Nikitin, D. I., Lysenko, A. M. \& Abraham, W.-R. (2005). Brevundimonas mediterranea sp. nov., a non-stalked species from the Mediterranean Sea. Int J Syst Evol Microbiol 55, 479-486.

Gerhardt, P., Murray, R. G. M., Wood, W. A. \& Krieg, N. R. (1994). Phenotypic characterization. In Methods for General and Molecular Bacteriology, pp. 607-654. Edited by P. Gerhardt. Washington DC: American Society for Microbiology.

Gomori, G. (1955). Preparation of buffers for use in enzyme studies. In Methods in Enzymology, vol. 1, pp. 138-146. Edited by S. P. Colowick \& N. O. Kaplan. New York: Academic Press.

Jeon, C. O. \& Park, J. M. (2000). Enhanced biological phosphorus removal in a sequencing batch reactor supplied with glucose as a sole carbon source. Water Res 34, 3470-3480.
Jeon, C. O., Lee, D. S. \& Park, J. M. (2003). Microbial communities in activated sludge performing enhanced biological phosphorus removal in a sequencing batch reactor. Water Res 37, 2195-2205.

Jeon, C. O., Lim, J. M., Lee, J. M., Xu, L. H., Jiang, C. L. \& Kim, C. J. (2005). Reclassification of Bacillus haloalkaliphilus Fritze 1996 as Alkalibacillus haloalkaliphilus gen. nov., comb. nov. and the description of Alkalibacillus salilacus sp. nov., a novel halophilic bacterium isolated from a salt lake in China. Int J Syst Evol Microbiol 55, 1891-1896.

Kimura, M. (1980). A simple method for estimating evolutionary rates of base substitutions through comparative studies of nucleotide sequences. J Mol Evol 16, 111-120.

Komagata, K. \& Suzuki, K. (1987). Lipid and cell wall analysis in bacterial systematics. Methods Microbiol 19, 161-208.

Lane, D. J. (1991). 16S/23S rRNA sequencing. In Nucleic Acid Techniques in Bacterial Systematics, pp. 115-175. Edited by E. Stackebrandt \& M. Goodfellow. Chichester, UK: Wiley.

Lanyi, B. (1987). Classical and rapid identification methods for medically important bacteria. Methods Microbiol 19, 1-67.

Leifson, E. (1963). Determination of carbohydrate metabolism of marine bacteria. J Bacteriol 85, 1183-1184.

Leifson, E. \& Hugh, R. (1954). A new type of polar monotrichous flagellation. J Gen Microbiol 10, 68-70.

Li, Y., Kawamura, Y., Fujiwara, N., Naka, T., Liu, H., Huang, X., Kobayashi, K. \& Ezaki, T. (2004). Sphingomonas yabuuchiae sp. nov. and Brevundimonas nasdae sp. nov., isolated from the Russian space laboratory Mir. Int J Syst Evol Microbiol 54, 819-825.

Lim, J. M., Jeon, C. O., Park, D. J., Kim, H. R., Yoon, B. J. \& Kim, C. J. (2005). Pontibacillus marinus sp. nov., a moderately halophilic bacterium from a solar saltern, and emended description of the genus Pontibacillus. Int J Syst Evol Microbiol 55, 1027-1031.

Mino, T., Arun, V., Suzuki, Y. T. \& Matsuo, T. (1987). Effect of phosphorus accumulation on acetate metabolism in the biological phosphorus removal process. In Biological Phosphate Removal from Wastewaters, pp. 27-38. Edited by R. Ramadori. Oxford: Pergamon Press.

Sambrook, J. \& Russell, D. W. (2001). Molecular Cloning: a Laboratory Manual, $3^{\text {rd }}$ edn. Cold Spring Harbor, NY: Cold Spring Harbor Laboratory.

Segers, P., Vancanneyt, M., Pot, B., Torck, U., Hoste, B., Dewettinck, D., Falsen, E., Kersters, K. \& De Vos, P. (1994). Classification of Pseudomonas diminuta Leifson and Hugh 1954 and Pseudomonas vesicularis Büsing, Döll, and Freytag 1953 in Brevundimonas gen. nov. as Brevundimonas diminuta comb. nov. and Brevundimonas vesicularis comb. nov., respectively. Int J Syst Bacteriol 44, 499-510.

Tamaoka, J. \& Komagata, K. (1984). Determination of DNA base composition by reversed-phase high-performance liquid chromatography. FEMS Microbiol Lett 25, 125-128.

Thompson, J. D., Higgins, D. G. \& Gibson, T. J. (1994). CLUSTAL W: improving the sensitivity of progressive multiple sequence alignment through sequence weighting, position-specific gap penalties and weight matrix choice. Nucleic Acids Res 22, 4673-4680.

Yoon, J.-H., Kang, S.-J., Oh, H. W., Lee, J.-S. \& Oh, T.-K. (2006). Brevundimonas kwangchunensis sp. nov., isolated from an alkaline soil in Korea. Int J Syst Evol Microbiol 56, 613-617. 